\title{
Carl Schmitt and the American Century
}

\begin{abstract}
During the past two decades or so, Carl Schmitt (1888-1985) has been read both as a mediated source of intellectual influence on the mainstream American Right, and as a radical critic of dominant US foreign policy discourses. This article offers an analytical reconstruction of Schmitt's interpretation of American foreign policy on the backdrop of this apparent paradox in the reception of his legacy. Through an engagement with a wide range of well-known and less well-known texts, the study draws particular attention to the philosophical prisms through which Schmitt came to conceptualise the relationship between technology, political violence and 'values' in the formulation of American foreign policy during the second half of the twentieth century. Although this is a more sinuous path to Schmitt's international political thought, it provides an understanding of his antagonism towards America that goes beyond the atavistic nostalgia of his own politics, and generates apposite insights into the webs of confused categories concerning war, space and historical time hardwired in the normative fabric of the so-called 'American century'.
\end{abstract}

Keywords: Values, Technology, War, Nuremberg, America, Schmitt, Hobbes, Realism

This article offers an exegesis of the US foreign policy narrative nested in the political thought of the German jurist Carl Schmitt (1888-1985). Along with his friend Martin Heidegger (1889-1976), Schmitt is one of the most controversial thinkers of the twentieth century. His career as a legal theorist and public intellectual defies the sort of short, snappy introduction that has come to be expected of academic writers in our contemporary publishing culture. So let me instead begin by stating the obvious.

Unlike many other writers who left a mark on the intellectual history of American foreign policy during the twentieth century, Schmitt never had any insider's understanding of the US foreign policy making process. Schmitt experienced US foreign policy at the receiving end. After being arrested and then released by the Red Army in Berlin in April 1945, he was arrested again by the Americans at the end of September and detained in various camps as a potential defendant for participation in a 'conspiracy to wage aggressive war' at the proceedings of the Nuremberg International Military Tribunal. According to one of his political biographers, 'the decision to interrogate him at Nuremberg was largely due to the infamous reputation he had acquired abroad . . . as the "Crown Jurist" of the Third Reich and the theorist of Nazi expansionism'. ${ }^{1}$ Schmitt owed this mythical reputation in great part to Frankfurt School intellectuals Franz Neumann, Otto Kirchheimer and Herbert Marcuse, who fled the Nazi regime during the interwar period and found refuge in the United States. During the war, the Research and Analysis Branch of the U.S. Office

\footnotetext{
${ }^{1}$ Joseph W. Bendersky, 'Carl Schmitt at Nuremberg', Telos, no. 72, 1987, p. 91
} 
of Strategic Services (a precursor to the CIA) recruited the three Marxist scholars to help them understand the Nazi state. ${ }^{2}$ After the war, Neumann became Chief of Research for Justice Robert H. Jackson, the chief prosecutor for the United States at Nuremberg. He personally made sure that Schmitt was detained, and that he was confronted by his friend and colleague in charge of the interrogations for the Americans, the German-born Jewish American lawyer Robert Kempner.

Being the vain and opportunist scholar that he was, Schmitt made no effort at downplaying the significance that his work had on German intellectual debates since the 1920s. But he dismissed all suggestions that he had any close direct contact with those within the Nazi executives who planned and conducted the war. As he wrote in his reply to Kempner and his team:

This is no place to expand upon the general situation of a university professor in a totalitarian system. Enough to say here that it was impossible for a chair in jurisprudence to be regarded as a decisive position or as a basis for exercising a decisive influence at decisive points in Hitler's totalitarian system, given its prevailing conception of science, education and jurisprudence... Theories and ideas do have influence, but this influence is not traceable to "decisive points". ${ }^{3}$

Schmitt never stood trial. But although he did indeed have nothing to do with the planning of the war and never succeeded in exercising 'decisive' influence over official Nazi legal theory, we know for a fact that the professor's involvement with the Nazis went well beyond the abstractions of academic debates. Schmitt joined the Nazi Party in 1933 and remained a member until the very end. Under the patronage of Herman Göring and Hans Frank, he was appointed to the Prussian State Council and became Director of the Berlin Faculty branch of the National Socialist Lawyers' Association (NSLA), where he also received a professorship. In June 1934, Schmitt was also appointed editor-in-chief of the Nazi news organ for lawyers, the Deutsche Juristen-Zeitung. In these different roles, he assisted with the drafting of Nazi legislation, contributed to the handling of various legal-administrative questions, and

\footnotetext{
${ }^{2}$ Franz Neumann, Herbert Marcuse and Otto Kirchheimer, Secret Reports on Nazi Germany: The Frankfurt School's Contribution to the War Effort, edited by Rafaelle Laudani (Princeton: Princeton University Press, 2013). See also Michael Salter, 'Neo-Fascist Legal Theory on Trial: An Interpretation of Carl Schmitt's Defence at Nuremberg from the Perspective of Franz Neumann's Critical Theory of Law', Res Publica, vol. 5, 1999, pp. 161-194.

${ }^{3}$ Carl Schmitt, 'Interrogation of Carl Schmitt by Robert Kempner', Telos, vol. 72, 1987, p. 128.
} 
defended the extra-judicial executions of Hitler's political rivals within the Nazi movement. ${ }^{4}$

Then when he began to lose influence after his denunciation for lack of ideological convictions by SS fanatics in 1936, Schmitt made a series of pathetic public interventions designed to draw attention to his commitment to anti-Semitism and official Nazi philosophy. His anxieties during this period can be read between the lines of his 1938 Leviathan in the State Theory of Thomas Hobbes: Meaning and Failure of a Political Symbol. After the war, Schmitt even claimed that the book was a form of esoteric resistance in which he used the Englishman as a mouthpiece to express his own subdued disappointment about Nazi orthodoxy. ${ }^{5}$ There is probably some truth in this. After all, Schmitt's Weimar writings always had more affinities with the fascist tradition exemplified by Maurras, Gentile, Mussolini and Franco than with the racially based totalitarianism of German National Socialism. ${ }^{6}$ But this is precisely the point. To the extent that his political and legal theory differed or deviated from official Nazi doctrines, there never was anything in there that could have served as a significant bulwark against a racist, totalitarian Nazi appropriation. ${ }^{7}$

But this does not really go to the bottom of things. For along with the reactionary tirades and revolting anti-Semitic tracts, Schmitt is also the author of some of the most thought provoking legal and political treatises written in the twentieth century. After being banned from post-war academic life, Schmitt went on to live a secluded life in his native town of Plettenberg. From there, he became a key background figure in the intellectual debates of the Federal German Republic, and published a number of important studies on various subjects including political theology, asymmetrical warfare and the emerging Cold War order. By far the most significant of these is his Nomos of the Earth in the International Law of the Jus Publicum Europaeum, which he wrote in the early 1940s but was only allowed to

\footnotetext{
${ }^{4}$ See Joseph W. Bendersky, Carl Schmitt: Theorist for the Reich (Princeton: Princeton University Press, 2014), and Reinhard Mehring, Carl Schmitt: A Biography (Cambridge: Polity Press, 2014).

${ }^{5}$ See George Schwab, 'Introduction' to Carl Schmitt, The Leviathan in the State Theory of Thomas Hobbes: Meaning and Failure of a Political Symbol, tr. G. Schwab and E. Hilfstein (Westport: Greenwood, 1996 [1938]).

${ }^{6}$ For a key statement see Carl Schmitt, 'Strong State, Free Economy', in Renato Cristi, Carl Schmitt and Authoritarian Liberalism (Cardiff: University of Wales, 1998), pp. 212-232.

${ }^{7}$ On this see John McCormick, 'Fear, Technology, and the State: Carl Schmitt, Leo Strauss, and the Revival of Hobbes in Weimar and National Socialist Germany', Political Theory, vol. 22, no. 4, 1994, pp. 619-652; Étienne Balibar, 'Le Hobbes de Schmitt, le Schmitt de Hobbes', 'Introduction' to Carl Schmitt, Le Léviathan dans la doctrine de l'état de Thomas Hobbes (Paris: Seuil, 2002).
} 
publish in $1950{ }^{8}$ In contemporary discourse, the Greek term 'nomos' is usually translated as 'law', 'norm' or 'regulation'. But Schmitt uses it in its original spatial meaning to designate the concrete division and redistribution of the earth that grounds public and international law in any historical period. Although certainly not without its suspicious omissions and analytical shortcomings, Schmitt's Nomos is an erudite account of the rise and fall of the modern Eurocentric global order, which concludes with a deeply critical analysis of the prospects for a new world order grounded in American power.

For obvious reasons, Schmitt's Nomos has been largely ignored in the AngloSaxon world during the entire duration of the Cold War. However, the collapse of communism and the subsequent attacks of $9 / 11$ have breathed new life into his analyses, generating an important new wave of secondary literature and translations of his works into English. ${ }^{9} \quad$ Along the way, observers have also identified important affinities between Schmitt's critique of liberalism and the confrontational style of 'friend and enemy' politics pursued by the American Right at home and abroad over the past few decades. This controversial issue of lineage is to do mainly with the influence exercised by conservative European immigrants and German Jewish refugees such as Joseph Schumpeter, Friedrich von Hayek and Leo Strauss, who in all sorts of complex and mediated ways acted as an intellectual 'transmission belt' between the authoritarian milieu of interwar Europe and neoconservative critiques of the liberal state. ${ }^{10}$

Within the discipline of International Relations, intellectual historians have also drawn attention to the important formative influence that Schmitt exercised on the young Hans Morgenthau. As we know, Morgenthau sought refuge in America during the interwar period and went on to become one of the leading figures of the post-war

\footnotetext{
${ }^{8}$ Carl Schmitt, The Nomos of the Earth: In the International Law of the Jus Publicum Europaeum, tr. G.L. Ulmen (New York: Telos Press, 2006 [1950]).

${ }^{9}$ For an important early engagement see Gary Ulmen, 'American Imperialism and International Law: Carl Schmitt on the US in World Affairs', Telos, vol. 72, 1987, pp. 43-71. For an overview of the rapidly expanding literature in English see Louiza Odysseos and Fabio Pettio (eds.), The International Political Thought of Carl Schmitt: Terror, Liberal War and the Crisis of Global Order (London: Routledge, 2007). For a rigorous Marxist critique see Benno Teschke, 'Fatal Attraction: a Critique of Carl Schmitt's International Political and Legal Theory', International Theory, vol. 3, no. 2, 2011, pp.179-227.

${ }^{10}$ William Scheuerman, Carl Schmitt: The End of Law (New York: Rowan \& Littlefield, 1999), pp. 183-208, 209-224; Heinrich Meier, Carl Schmitt and Leo Strauss: The Hidden Dialogue (Chicago: Chicago University Press, 1995); Jean-François Drolet, American Neoconservatism: The Politics and Culture of a Reactionary Idealism (New York: Columbia University Press, 2011).
} 
realist tradition. ${ }^{11}$ Schmitt's subterranean presence in realist circles during the following decades was also ensured by George D. Schwab, the American foreign policy expert of Latvian-Jewish descent with whom Morgenthau founded the National Committee on American Foreign Policy (NCAFP) in 1974. The NCAFP is a centreright think tank dedicated to the advancement of American foreign policy interests 'from a nonpartisan perspective within the framework of political realism'. ${ }^{12}$ Schwab has been the director since the early 1990s. In his functions as the English-language executor of the Schmitt Estate, he has translated three of Schmitt's most important works, and published the first overview of his political philosophy in the Englishspeaking world in $1970 .^{13}$ Schwab has also been instrumental to the intriguing transformation of Paul Piccone's influential academic journal Telos since the late 1980s, from a New Left vehicle for the dissemination of Frankfurt School Critical Theory in the US into an outlet for forgotten or repressed critics of mainstream liberalism on both sides of the political spectrum - Schmitt being the most significant of them. The other prominent Schmitt scholar who contributed to this transformation is the leading 'paleoconservative' intellectual historian of American conservatism Paul Gottfried. Gottfried was a close friend of Richard Nixon, and has been a longtime political adviser to Pat Buchanan.

In sum, what has become clear to us during the past two decades or so is that Schmitt's oeuvre is much more important to the intellectual history of American political thought than it was ever thought to be - both as a mediated source of influence and as vehicle for radical criticism. In what follows, I reconstruct Schmitt's interpretation of US foreign policy with an eye to this ambivalence structuring the reception of his legacy in the English-speaking world. The analysis draws particular attention to the philosophical prisms through which Schmitt came to conceptualise the relationship between technology, political violence and universal 'values' during the second half of the twentieth century. Although this is a somewhat more sinuous path to Schmitt's international political thought, it provides an understanding of his antagonism towards America that goes beyond the atavistic nostalgia of his own

\footnotetext{
${ }^{11}$ Hans J. Morgenthau, The Concept of the Political, edited and introduced by Hartmut Behr and Felix Rosch (London: Palgrave, 2012); Christopher Frei, Hans J. Morgenthau, An Intellectual Biography (Baton Rouge: Louisiana University Press, 2001); Martii Koskenniemi, The Gentle Civilizer of Nations (Cambridge: Cambridge University Press, 2010), pp. 413-509; Scheuerman, Carl Schmitt, pp. 225-252.

${ }^{12}$ See www.ncafp.org/about-us/our-mission/ [7 April 2014].

${ }^{13}$ George Schwab, The Challenge of the Exception: An Introduction to the Political Ideas of Carl Schmitt 1921-1936 (New York: Praeger, [1970] 1989).
} 
politics, and generates apposite insights into the webs of confused categories concerning war, space and historical time hardwired in the normative fabric of the ‘American century'.

\section{Of States, Wars and Sea Monsters}

Our main point of entry into Schmitt's reading of American foreign policy is the aforementioned 1938 book on Hobbes. For although America is rarely ever mentioned in it, much of the conceptual framework that Schmitt brings to bear on his analyses of US foreign policy in subsequent studies is laid out here in his discussion of Hobbesian political theory.

As the title suggests, Leviathan in the State Theory of Thomas Hobbes: Meaning and Failure of a Political Symbol is a critical assessment of the achievements and failures of Hobbesian political theory from the not so contextual perspective of the turbulent 1930s. In the first instance, the book presents Hobbes's Leviathan as the most creative and influential justification of the absolutist political order that prevailed between the mid- $17^{\text {th }}$ century and the $19^{\text {th }}$ century - the so-called Jus Publicum Europaeum. In ideal typical form, the Jus Publicum Europaeum was a re-organisation of European public space into two clearly separated domains: a domain of political authority reserved for the sovereign and governed by the principle of raison d'état, and a subordinate domain of apolitical subjects where culture, morality and commerce developed according to their own immanent principles. As a symbolic representation of this European order, Schmitt argues that Hobbes's Leviathan 'achieved its highest degree of mythical force' by ensuring the preservation of an external space where sovereign states could affirm their 'force and vitality' against one another, and remind their subjects of the 'reasons' why the state was created in the first place. ${ }^{14}$ The absorption of all rationality and legality by the absolutist state meant that those who faced one another as enemies no longer did so as religious foes, but as states and according to the secular dictates of raison d'état: 'Wars become pure wars between states'. It follows from this that one could no longer talk of just and unjust wars between states since the juridical categories of the system of international law no longer took their bearing from a transcendent theology, but from the concept of the state and its immanent ethics of raison d'état: 'Ordo hoc

\footnotetext{
${ }^{14}$ Schmitt, The Leviathan, pp. 48-49.
} 
non includit. The state has its order in, not outside, itself' ${ }^{15}$

Schmitt considers this de-moralisation of warfare as one of the great humanising achievements of the age of absolutism. This is because war fighting took place on the basis of a clear distinction between civilians and combatants, and combat was operationalized on the basis of a strict hierarchical chains of command. Wars had to be lawfully declared; and they could be ended with formal peace treaties because their aims were of limited and primarily material character. To be sure, none of this applied in the Americas or anywhere beyond the European continent, where European powers showed little restraint towards non-white civilian populations and in their conflicts with one another. And even within Europe, the ideal of 'bracketed, cabinet warfare' as a gentlemanly duel was just that - i.e. an ideal that was routinely ignored and violated. But what fascinated Schmitt is that this ideal of limited, regulated warfare was upheld in the first place.

And yet, Schmitt argues that it is precisely the absence of a genuinely transcendent political theology in the Hobbesian concept of the state that would eventually lead to the decline of the absolutist order. ${ }^{16}$ The crux of the argument is that Hobbes's Leviathan owes its demise to the strict separation between morality proper and the self-referential ethics of the state upon which it was erected. Under the doctrine of raison d'état, the absolutist state took leave from traditional moral norms and subordinated all religious and rational claims of individual morality to political necessity. But in doing so, it created a foothold for the emergence of a private realm autonomous from the state where a well-financed and intellectually influent civil society would grow and acquire a monopoly on 'morality proper'. Because Hobbes considered freedom from politics to be the ultimate moral good, he could not have conceived that the emergence of a bourgeois civil society could be a potential political threat to the state. Yet, it is precisely this moral rejection of politics that established a comfortable critical vantage point from which the immoral substance of the absolutist order would eventually be put into question by a civil society emancipated from the state of nature. For as the secularizing process continued to unfold in the $17^{\text {th }} 18^{\text {th }}$ and $19^{\text {th }}$ centuries, the new bourgeois public sphere progressively turned its attention away from religion and began to exercise its critical spirit on earthly matters. It slowly

\footnotetext{
${ }^{15}$ Ibid., pp. 47-48.

${ }^{16}$ Ibid., pp. 33-34.
} 
extended itself into politics through legal criticism enunciated from within the realm of government, until it eventually turned against the state itself.

Schmitt argues that Hobbes's Leviathan fell short of serving its ordering function because its mythical element failed to establish a clear political distinction between 'us and them' and 'friend and enemy', which transcends the public-private distinction and cultivates the cultural homogeneity of the political community. Schmitt's suggestion is that the heterogeneous elements of 'society' could only be maintained as long as the 'civil society versus state' line of enmity existed. When this strict opposition progressively dissolved, enlightenment criticism failed to reconcile its anti-political morality with the amorality of the political realm. As a mode of social integration, moral critique could not succeed without succumbing to the autonomy and primacy of the political: "The old adversaries, the "indirect" powers of the church and of interest groups, reappeared in that century as modern political parties, trade unions, social organizations, in a phrase, as "forces of society" [...] The institutions and concepts of liberalism became weapons and power positions in the hands of the most illiberal forces'. ${ }^{17}$

But that is not all. According to Schmitt, Hobbes's poor 'mythological sense' had led him to choose a sea monster over the terrestrial monster Behemoth to capture the symbolic essence of his treatise on the sovereign territorial state. Hobbes's confused choice of biblical creature reflected his blindness to the political passage from land to sea that was in the process of transforming England since the Elizabethan era. As Schmitt points out, the Hobbesian ideal of the state realised itself on the continent, mainly in France and in Prussia, but never in England: 'The English Isle and its world-conquering seafaring needed no absolute monarchy, no standing land army, no state bureaucracy, no legal system of a law state such as became characteristic of continental states... the English people withdrew from this kind of closed states and remained "open", ${ }^{18}$ Those who created the British Empire were privateers (individuals who considered maritime violence a private matters), commercial adventurers, immigrants and other social forces associated with the Puritan revolution, and who found in colonial expansion a means to escape from the hierarchical politics of statehood.

\footnotetext{
${ }^{17}$ Ibid., pp. 73-74.

${ }^{18}$ Ibid., p. 80 .
} 
According to Schmitt, this would in great part account for the indirect methods, channels and means by which British sovereignty came to be exercised in the world: Free Masonry, liberal constitutionalism, industrialism and other such consequences and by-products of Britain's de-territorialised relationship to machinery and techne. As the earth came to be increasingly envisaged from the perspective of the sea, a 'virtual geography' transmuted itself into a genuine 'political reality' completely antithetical to continental political and juridical institutions. Unlike the continental order, which rested on closed delimitated spaces, the sea would remain free and opened to commercial and war-making activities. It would 'belong to nobody, or everybody, but in reality, it would belong to a single country: England'. ${ }^{19}$ And as Schmitt is keen to point out, these basic spatial premises also generated two antithetical conceptions of warfare and enmity:

[T]he naval wars were based on the idea of the necessity of treating the enemy's trade and economy as one. Hence the enemy was no longer the opponent in arms alone, but every inhabitant of the enemy nation, and ultimately every neutral country that had economic links with the enemy. Land warfare implied a decisive confrontation in the field. While not excluding naval combat, the maritime war, on the other hand, favored such characteristic means as bombardment, the blockade of the enemy shores, and the capture of enemy and neutral merchantmen in virtue of the right to capture. ${ }^{20}$

Schmitt dates the official disintegration of the Jus Publicum Europaeum to the great scramble for Africa and the Congo Conference of 1885. The subsequent Hague Peace Conferences of 1899 and 1907 marked the transition from a Eurocentric world order to one rooted in the spacelessness of an abstract, general universalism. By then, the industrial revolution had completely 'transformed the children of the sea into machine-builders and servants of machines'. ${ }^{21}$ For Schmitt, however, the end of the British hegemony, the First World War, decolonization, and the establishment of the League of Nations did not so much mark the expansion of the European state system to the rest of the world as its superseding by a new Großräume order driven by the rise of American power.

\footnotetext{
${ }^{19}$ Carl Schmitt, Land and Sea, tr. Simona Draghici (Washington D.C.: Plutarch Press, [1942] 1997), p. 46.

${ }^{20}$ Ibid., pp. 47-48.

${ }^{21}$ Ibid., p. 54.
} 


\section{America and the Großräum Order}

Schmitt's concept of Großräume refers to the geographical delimitation of a state's special 'sphere of interests', or 'zone of security', extending way beyond its legal territorial borders. The politics of Großräume would therefore be a politics of supranational formations, in which the globe would be divided among a small number of hegemonic powers seeking to guarantee the integrity and independence of subordinate states on the basis of their political homogeneity. ${ }^{22}$ Schmitt would come to read the Second World War in this optic as the first war for the organisation of planetary space, the meaning and significance of which he did not see in the fight against Soviet Russia but in the struggle against Great Britain and Roosevelt's America.

Like many analysts at the time, Schmitt understands the dissolution of the colonial empires to be an implicit motive for the United States late entry into the war in December 1941. He traces the intellectual origins of this grand strategy in the writings of the American Admiral Alfred Thayer Mahan (1840-1914). In July 1894, Mahan published an article in which he explored the possibility of a re-unification between Great Britain and the United States. Mahan considered racial, linguistic and cultural commonalities to be important sources of motivations. But for him it was geography and the need for Anglo-Saxon geopolitical security that provided the primary rationale: 'In the evolving modern world, England had grown too small'. Just as Disraeli had proposed to displace the seat of the declining Empire from London to Delhi in the 1840s, Mahan now saw America as 'the larger island, through which the British mastery of the seas would be perpetuated as an Anglo-American maritime dominion of the world on a larger scale'. ${ }^{23}$ For the Admiral, the old continental conception of the 'Western hemisphere' at the heart of the Monroe Doctrine had run its course. The time had come to move towards the pacific and submit vast new spaces to the new 'open door' policy of the United States.

The originality of Schmitt's analysis lies in the metaphysical significance that he reads into this betrayal of the Monroe Doctrine. In his 1941 book Völkerrechtliche Großraumordnung (The Regional Order in International Law), Schmitt

\footnotetext{
${ }^{22}$ Carl Schmitt, 'Großraum gegen Universalismus' (1939), in Positionen und Begriffe im Kampf mit Weimar-Genf-Versailles, 1923-1939 (Berlin: Duncker \& Humblot [1940] 1994), pp. 335-343. See also Carl Schmitt, 'The Großraum Order of International Law with a Ban on Intervention for Spatially Foreign Powers: A Contribution to the Concept of Reich in International Law (1939-1941), in Writings on War, tr. Timothy Numan (Cambridge: Polity Press, 2011).

${ }^{23}$ Schmitt, Land and Sea, p. 55.
} 
controversially argues that ' $[\mathrm{t}]$ he 1823 Monroe Doctrine was in the recent history of international law the first and to date most successful example of a regional [Großraum] international law. That is the real precedent for the German Reich'. ${ }^{24}$ Originally formulated by John Quincy Adam (1767-1848), the Monroe Doctrine stipulated that no more colonisation and extension of the European system would be allowed anywhere in the Western hemisphere. In guise of reciprocity, the US would not interfere with the existing European colonies in the New World or with the internal affairs of European nations. ${ }^{25}$ The Monroe doctrine thus established the basis of a world based on two geopolitical 'spheres of influence' transcending existing regimes of state sovereignty. It also affirmed the Western hemisphere as a US regime of freedom, justice, peace, virtue and self-determination against the old and morally corrupted order of European absolutism. According to Schmitt, the goal of this negative identification with the 'old occident' was not to fragment or 'dethrone' the idea of the occident as such, but to take its place as the main 'axis of world history and centre of the world'. ${ }^{26}$ Through this expansionist act of geopolitical isolation, the Monroe Doctrine limited European presence in the Western hemisphere and preserved the independence to act unilaterally, conquer and settle the remaining parts of the West.

In light of the parliamentary corruption and degeneracy of European absolutism during the eighteenth century, and given the servile character of the post-Napoleonic reaction and restoration during the nineteenth century, America appeared to stand a real chance of becoming the more authentic representative of the European ideal. As Schmitt points out, after the bourgeois revolutions of 1848, thousands of disillusioned intellectuals and political activists fled the old reactionary continent and immigrated to America in the hope of finding a more receptive audience for their transformative visions. ${ }^{27}$ In concrete geopolitical terms, however, the pronouncement of the Monroe Doctrine in 1823 was of limited significance. For the United States neither had the navy nor the military power to enforce such an ambitious policy pronouncement. It

\footnotetext{
${ }^{24}$ Carl Schmitt, Völkerrechtliche Großraumordnung (Berlin: Deutscher Rechtsverlag, 1941), p. 13. My translation.

${ }^{25}$ Bradford Perkins, The Creation of a Republican Empire: 1776-1865 (Cambridge: Cambridge University Press, 1993), pp. 147-169.

${ }^{26}$ Carl Schmitt, 'Changement de structure du droit international', in La Guerre Civile Mondiale. Essais (1943-1978), tr. Céline Jouin, (Alfortville: Ere, [1943] 2006), p. 39. This is a conference paper that Schmitt gave in Spanish at the Instituto de Estudios Politicos in Madrid on 1 June 1943.

${ }^{27}$ Ibid., p. 40.
} 
went relatively unnoticed abroad for the best part of the nineteenth century, and was randomly violated by European powers at several occasions. By the time America had acquired the maritime capability to enforce its declared Großräume at the turn of the century, optimistic beliefs about the novelty, liberty and possibilities of the Western hemisphere had all but completely disappeared.

In line with contemporary Marxist theories, Schmitt argues that the opening of new imperialist horizons towards Asia under Roosevelt was inexorably linked to a domestic contraction of economic opportunities. Schmitt invokes John Dewey's appropriation of Frederick Jackson Turner's famous 'frontier thesis'. ${ }^{28}$ The frontier thesis argued that many of the dominant attributes of American culture like individualism, democracy and civic nationalism had been made possible and depended on Westward expansion across the American continent. ${ }^{29}$ The early success and wide appeal of American democracy was predicated on the abundant availability of cheap agricultural land, and on the interpretation of democratic freedom as the freedom to own and accumulate property unimpaired by government. This allowed for a relatively high level of social mobility, which in turn strengthened the belief that individual effort leads to individual achievement. It also helped account for the perception of a situation of relatively widespread economic equality in the United States compared to Europe during the $18^{\text {th }}$ and $19^{\text {th }}$ century. But this period came to an end with the closing of the Western frontiers in the early 1890s. America's 'living space' was now limited and could no longer rely on this geographical safety valve to guarantee its continued stability and prosperity:

At this moment, America's nomos - i.e. the foundations of all social and legal relations changed completely... More rapidly than anyone could have anticipated, the new Europe was transformed into a vulgar and enlarged image of the old one. The social question, problems of demographics, race, unemployment and political freedoms - all presented themselves as in Europe but on a much larger scale and with ten times the intensity. ${ }^{30}$

Although there was relatively little disagreement within the economic and political elites that expansion was necessary, this expansion had to be formulated in

\footnotetext{
${ }^{28}$ Ibid., p. 41.

${ }^{29}$ Frederick Jackson Turner, 'The Significance of the Frontier in American History' (1893), re-printed in The Frontier in American History (New York: Holt, 1921), pp. 30-52.

${ }^{30}$ Schmitt, 'Changement', p. 41. My translation.
} 
ways that did not offend the cultural tradition of liberty, self-determination and progress so central to discourses of American identity. Roosevelt did this by 'exploiting the Monroe Doctrine and using it as a pretext to promote a particularly rude form of liberal capitalist "dollar diplomacy", 31 Roosevelt's dollar diplomacy was anchored in a broader foreign policy vision characterised by an unstable mixture of progressive and social-Darwinian concerns over the debilitating consequences of mass consumerism on American society. ${ }^{32}$ These tensions found expression in his exaltation of martial virtues and his belief that America had an obligation to use its growing military and industrial capability to develop and modernize the 'wasted spaces' of the earth in the interest of humanity as a whole. As he told a crowd in a famous speech shortly after his inauguration: 'Chronic wrongdoing may in America, as elsewhere, ultimately require intervention by some civilized nation, and in the Western Hemisphere the adherence of the United States to the Monroe Doctrine may force the United States, however reluctantly, in flagrant cases of such wrongdoing or impotence, to the exercise of an international police power'. ${ }^{33}$

According to Schmitt, the 'Roosevelt corollary' to the Monroe Doctrine rested on a dual conflation of practices that had very significant implications for the exercise of American foreign policy in the twentieth century. The first concerns the merging of two sets of political commitments that are both geographically and normatively antithetical to one another. Whereas the Monroe Doctrine is based on an authentic notion of space implying concrete limitations, dollar diplomacy has nothing but contempt for spatial boundaries:

The sanctified tradition of always being the country of free land is underpinned by a consequent isolationism. Yet the imperial reality of economic ambitions in world commerce calls for unlimited universal intervention. The traditional separation of commerce from politics - as much commerce as possible and as little politics as possible - has lost its inner truth because, in the long run, there cannot be any world commerce without world politics. ${ }^{34}$

\footnotetext{
${ }^{31}$ Schmitt, 'Großraum gegen Universalismus', p. 336.

${ }^{32}$ See Frank Ninkovich, 'Theodor Roosevelt: Civilization as Ideology', Diplomatic History, vol. 10, no. 3, 1986, pp. 222-30.

33 'Transcript of Theodor Roosevelt Corrolary to the Monroe Doctrine' (1905), http://www.ourdocuments.gov/doc.php?doc=56\&page=transcript, [22/04/2015].

${ }^{34}$ Carl Schmitt, 'Beschleuniger wider Willen oder: Problematik der Westlichen Hemisphäre', in Staat, Großraum, Nomos, Arbeiten aus den Jahren 1916-1969 (Berlin: Duncker \& Humblot, 1995), pp. 431437. This text originally appeared in the Nazi Party weekly Das Reich on 19 April, 1942. My translation.
} 
What is really important for Schmitt in these developments is the shift in the ethico-political disposition that characterises America's act of self-isolation from the rest of the world. Many other peoples, states and empires have in the past sought to draw defensive geopolitical lines to quarantine themselves from external contaminations. Schmitt draws attention to the Great Wall of China and the Pillars of Hercules flanking the entrance to the Straight of Gibraltar as examples of such symbolic frontiers. What is different with the Roosevelt corollary is that the defensive and spatially demarcated line of self-retrenchment constitutive of the Monroe Doctrine mutates into its opposite - i.e. a spaceless, offensive line of discrimination against the rest of the world that demands integration and adherence to a substantively prescribed normative order. ${ }^{35}$

Wilsonian liberal internationalism, with its encouragement to 'all the peoples of the world' to adopt the right to self-determination, was a logical extension of the Roosevelt corollary. This was followed by the Stimson Doctrine of 1932, which reiterated America's right to deny recognition to any state or government anywhere in the world that did not come to power through 'legitimate' means. It did so, for example, by maintaining the convention of recognizing not states but only governments considered 'lawful' according to the United States own understanding of legality. The Stimson doctrine was pronounced on the juridical basis of the KellogBriand Pact of 1928 and the covenant of the League of Nations. In this same discriminatory spirit, the League not only appropriated the universal right to determine which side of a conflict was 'just and unjust', but also claimed the authority to impose this decision on all neutral parties. The move was facilitated by a discursive re-articulation of interstate conflicts in terms of a series of oppositions between the League's 'pacifying interventions' and the 'crimes' and 'terrorism' of its opponents. And because no one can remain neutral in the face of terror and crime, the League effectively transformed the pacific concept of neutrality into a concept of war. $^{36}$

This is the other main source of Schmitt's resentment against American foreign policy. For the jurist, 'police' refers to the legitimate use of force by the sovereign state to secure the domestic order. It must not be conflated with the activity of

\footnotetext{
${ }^{35}$ Schmitt, 'Changement', pp. 41-42.

${ }^{36}$ Carl Schmitt, 'The Turn to the Discriminating Concept of War', in Writings on War, pp. 30-74.
} 
warfare occurring strictly between sovereigns: 'War in this system of international law is a relationship of one order to another order, and not from order to disorder. This relationship of order to disorder is "civil war". 37 Schmitt traces the origins of this criminalization of war to the American entry into the Second World War. In the Nomos, he quotes specifically from the March 31, 1941 proclamation of Justice Jackson, the then US attorney general, who explicitly confirmed the change from an older understanding of war to a new order where aggression will be punished. ${ }^{38}$ Schmitt sees important parallels between these developments and the theological just war tradition that had been abandoned with the emergence of the Jus Publicum Europaeum. ${ }^{39}$ Yet against the opinion of the American jurist James Brown Scott, he insists that the emergence of this new discriminatory conception of war should be seen as a completely new ideological phenomenon associated with the industrialtechnological development of late-modern means of destruction:

This is not the 'just' war of Middle-Ages theologians, of which spoke Vittoria and, under his influence, Grotius and the internationalists of the seventeenth and eighteenth centuries. This attempt at eliminating one's political adversary by portraying him as a criminal and the ultimate obstacle to world peace is radically new because it embraces the whole world... By claiming not only the right to defend itself against a political adversary, but also the right to disqualify and slander this adversary from the point of view of international law, Washington intends to introduce humanity to a new type of war in international law. For the first time in history, war is a global world war. ${ }^{40}$

\section{Nuremberg and the Tragic Limits of International Law}

What should we make of these claims? As various commentators have pointed out, the obvious problem with Schmitt's narrative is that it suggests that it was the United States who unilaterally transgressed and discredited classical doctrines of war, diplomacy and international law by declaring war on Germany in 1941. By emphasising the moralisation of the political at the heart of America's discourse on war, and associating it with changes in technologies of warfare, Schmitt implicitly normalises Hitler's genocidal war in Europe as a classic conflict of 'reason of state'

\footnotetext{
${ }^{37}$ Schmitt, 'The Großraum Order', p. 105.

${ }^{38}$ Schmitt, Nomos, pp. 297-298.

${ }^{39}$ Schmitt, 'Changement', p. 43.

${ }^{40}$ Schmitt, 'Changement' p. 43. My translation.
} 
fought between Großräume. It is almost as if the war of extermination fought by the Nazis and the Wehrmacht had nothing to do with America's appropriation of the just war paradigm as a framework to address these atrocities. ${ }^{41}$

This seriously undermines the analytical credibility and ethical status of Schmitt's critique. Yet it is important that we do not reduce our assessment of Schmitt's enterprise to this apparent normalisation of Nazi atrocities, lest we will fail to understand the nuances, ambiguities and continued significance of his analyses despite their dubious motivations and conclusions. Further insights can be gleaned from Schmitt's reflections on the Nuremberg trials.

Here again, Schmitt seems a lot more anxious to debunk Allies justifications of the Nuremberg criminalisation of warfare than he is with acknowledging the 'rights' of the victims of Nazi atrocities. Whenever he refers to the participation of the Wehrmacht in the mass killings of civilians and the Holocaust, he primarily does it to draw a distinction between the undeniable guilt of the German high command and the much more ambiguous responsibility of 'ordinary Germans' who were only indirectly or passively involved. According to Schmitt, international law could not possibly expect civilians to make their own judgement on 'just' and 'unjust' wars and commit treason against their own country simply by fear of being prosecuted for complicity in war crimes. ${ }^{42}$ For those who contemplated treason or resistance against their own state at the time had absolutely no legal reason to expect significant protection from international institutions. Non-resistance to the Nazi leviathan may well have been cowardly, but it was certainly not the same as collaboration and could hardly be treated as an aggressive crime. If Nazi Germany was condemned for walking over the 1907 Hague Convention on the laws of war, then the victors also had to comply to the terms of the said Convention that they were enforcing. ${ }^{43}$

As Schmitt saw it, the fundamental problem with Nuremberg was that the trials had been instituted so as to exclude the possibility of ascribing responsibility for the

\footnotetext{
${ }^{41}$ Peter Uwe Hohendahl, 'Reflections on War and Peace After 1940: Ernst Jünger and Carl Schmitt', Cultural Critique, vol. 69, 2008, pp. 22-51; Chris Brown, 'From Humanised War to Humanitarian Intervention: Carl Schmitt's Critique of the Just War Tradition', in Odysseos and Pettio, The International Political Thought of Carl Schmitt, pp. 56-70; Benno Teschke, 'Carl Schmitt's Concept of War: A Categorical Failure', in Jens Meierheinrich and Oliver Simmons (eds.), The Oxford Handbook of Carl Schmitt (Oxford: Oxford University Press, 2015).

${ }^{42}$ Gary Ulmen, 'Just Wars or Just Enemies', Telos, vol. 109, p. 111.

${ }^{43}$ Carl Schmitt, Das internationalrechtliche Verbrechen des Angriffskrieges und der Grundsatz 'Nullen crimen, nulla poene sine lege, ed. Helmut Quaritsch (Berlin: Duncker \&Humblot, [1945] 1994), pp. 76-78. See also Céline Jouin, 'Carl Schmitt à Nuremberg. Une théorie en accusation', Genèse, no. 74, 2009, pp. 46-73.
} 
causes of the war, and to criminalise the 'aggression' as such. This amounted to a politically motivated de-politicisation of legalism that would have serious debilitating consequences for the future credibility of international law. Although Schmitt denied all legal plausibility to Allies accusations concerning Germany's war motivations and responsibility, he agreed unreservedly that Germany had to be punished for the Holocaust and traditional crimes of war. But while traditional war crimes could be dealt with under the existing laws of war, he insisted that the violence of the Holocaust exceeded the scope of existing categories of positive public and international law. Instead, Schmitt argued that the atrocities committed by Hitler's regime were so overwhelmingly extreme that SS and Gestapo high commands had to be brought before a tribunal to be condemned and punished very publicly on a moral rather than a juridical basis: 'There are problems for which Themis has no scale... The problem at Nuremberg was not to do with law as such, but with the limits of what men have a right to affirm as a right by means of a trial'. ${ }^{44}$

Schmitt sensed Justice Jackson's unease concerning the juridical process over which he presided. For when establishing collective responsibility for such largescale atrocities, no one can rest satisfied with the fact that the victors simply dictate their laws to the defeated. Schmitt understood the situation as a radical expression of the liminal dilemmas of the German idealist tradition. If it is the case that the victors dictate their laws to the defeated, and if the defeated simply accept this dictate submissively, then relations between victors and the defeated are nothing but meaningless relations of factual material power. On the other hand, if one is serious about the ideals invested in a given conflict, one must submit to the potentially suicidal either-or a priori logic inherent to all ideals, lest one abandons these ideals to a nihilistic, positivistic neutralism. While recognising German guilt, Schmitt constructed this guilt against the tragedy of the human condition. He saw this tragic sense of life as a characteristic feature of the German self-understanding, and from which one could derive a certain right to political 'error' that was a lot more human than the self-aggrandizing human rights discourse of his accusers:

\footnotetext{
${ }^{44}$ Carl Schmitt, Ex Captivate Salus: Erfahrungen der Zeit 1945/47 (Berlin: Duncker \& Humblot: 2002), 17-7-49, p. 258. Cf. Schmitt, Das internationalrechtliche Verbrechen, p. 16. See also Céline Jouin, Le retour de la guerre juste: Droit international, épistémologie et idéologie chez Carl Schmitt (Paris: Vrin: 2013) pp. 291-295.
} 
Empedocles' death, his heroic descent into the solar fire of the earth, and the releasing of atomic energy (that is to say unconstrained solar energy), these are one and the same thing. This is enlightenment philosophy, or the philosophy of the German spirit. It is in its name that the world conducts against us, we who anticipated this disaster, an idiotic war morally just. $^{45}$

Unlike what Jürgen Habermas has argued in an influential critique of his rightwing compatriot, Schmitt's position is therefore not that there exist no legitimate elements of normative universalism in world politics that can serve as a basis for social and moral criticism. ${ }^{46}$ On the contrary, the problem is that there is too much of it. Because no one can 'know' with certainty what these universals are, and how they should guide collective action, political communities will consciously or unconsciously mobilise universal moral tropes for their own particular political purposes. Given the legal difficulties associated with the lack of clear definition, sanctions, and organisational means of enforcement in international relations, Schmitt believed that the procedural rationalism of the Jus Publicum Europaeum constituted a better source of restraint against the tendency of substantive philosophical universalisms to degenerate into parochial irrationalism.

\section{Technology and the Cold War}

Schmitt's claim that America's rendition of the just war tradition expresses a new ideological phenomena attending to the technological development of contemporary means of violence must be read in the context of this distinctively German strain of political realism. Always implicit but never clearly stated in his polemics, the full force of Schmitt's thesis rides on the critique of technology that he developed during and after the First World War, and which spurred a important three-way exchange with his friends Martin Heidegger and Ernst Jünger during the 1920s and 1930s. ${ }^{47}$

\footnotetext{
${ }^{45}$ Carl Schmitt, Glossarium: Aufzeichnungen der Jahre 1947-1958, Gebundene Ausgabe, Eds. Gisler and M. Tielke (Berlin: Duncker \& Humbolt, 2015), 30/06/1949, p. 251.

${ }^{46}$ Jürgen Habermas, The Past as Future, tr. Max Pensky (Lincoln: University of Nebraska Press, 1994), pp. 9-10, 21-22.

${ }^{47}$ See Carl Schmitt, Theodor Däublers, 'Nordlicht': Drei Studien über die Elemente, den Geist und die Aktualität des Werkes (Berlin: Duncker \& Humblot, [1916] 1989), and 'The Age of Neutralizations and Politicizations' (1929), reprinted in his The Concept of the Political, tr. Tracy Strong (Chicago: Chicago University Press, [1927] 2007), pp. 80-97. See also John McCormick, Carl Schmitt's Critique of Liberalism: Against Politics as Technology (Cambridge: Cambridge University Press, 1997).
} 
Without going into the specific terms of agreement and disagreement of this exchange, the main thesis common to all three authors is that the seemingly neutral and soulless character of techne and mechanics is in fact driven by an anthropocentric metaphysics of control, production and distribution/redistribution which is rife with violence and antagonistic potential. This diagnosis hinges on the claim that technology is not only about material artefacts such as transportation, computing and communication 'systems' and 'machineries'. More fundamentally, it is a way of thinking in which humanity itself becomes absorbed as a source of supplies into the technical web of valuation, calculation and exchange that is the world as resource for exploitation, management and manipulation. Jünger gives the definitive statement in his famous interwar essay, 'Total Mobilisation':

The era of the well-aimed shot is already behind us. Giving out the night-flight bombing order, the squadron leader no longer sees a difference between combatants and civilians, and the deadly gas cloud hovers like an elementary power over everything that lives. But the possibility of such menace is based neither on a partial nor general, but rather a total mobilization. It extends to the child in the cradle, who is threatened like everyone else even more so.

It suffices simply to consider our daily life, with its inexorability and merciless discipline, its smoking, glowing districts, the physics and metaphysics of its commerce, its motors, airplanes, and burgeoning cities. With a pleasure-tinged horror, we sense that here, not a single atom is not in motion-that we are profoundly inscribed in this raging process. Total Mobilization is far less consummated than it consummates itself; in war and peace, it expresses the secret and inexorable claim to which our life in the age of masses and machines subjects us. ${ }^{48}$

Shortly after the American landing in North Africa in November 1942, Jünger wrote in his diary that the violence and animosity of the Second World War was a lot more intense than what he had experienced in the trenches during the First World War. Whereas WWI was fought over the metaphysics of the European nation-state, WWII felt more like a 'universal civil war' (Weltbürgerkrieg). ${ }^{49}$ Schmitt had

\footnotetext{
${ }^{48}$ Ernst Jünger, 'Total Mobilization', reprinted in Richard Wolin, The Heidegger Controversy: A Critical Reader (Cambridge MA: MIT Press, [1930] 1993), p. 128.

${ }^{49}$ Ernst Jünger, Tagebücher, in his Werke, vol. 2 (Stuttgart: Klett, 1962), p. 433
} 
developed the notion of universal civil war a few years earlier. ${ }^{50}$ In the conservative literature during the Cold War, the term universal civil war would often be used to discredit revolutionary hopes and activities, suggesting that the latter could never achieve their unrealistic aims and instead only fomented the prospects of endless violence. $^{51}$ But for Schmitt as for Jünger at the time, what also gave the Second World War the apparent quality of a universal civil war was the fact that the war stemmed from conflicts between imperial powers, which had been forced by increasing interdependence to preside 'together' in supranational institution over the dissolving of the Westphalian system of sovereign states into one single post-national normative order. As in civil war, what was at stake in the struggle between the mass ideologies of fascism, Bolshevism and liberalism was the nature of the social bond that would unite this emerging supranational polity. And because in an undivided polity only one party can hold a monopoly on legitimate violence, the defeated party must either be completely subdued or destroyed. This inevitably raised the stakes of the conflict as it implicitly ruled out the possibility of any compromise that might have allowed for the continued co-existence of the warring factions. ${ }^{52}$ As Schmitt explains in the Nomos:

Civil War has something gruesome about it. It is fraternal war, because it is pursued within a common political unity that includes also the opponent, and within the same legal order, and because both belligerent sides absolutely and simultaneously affirm and negate this common unity. Both consider their opponent to be absolutely and unconditionally wrong. Both reject the right of the opponent, but in the name of the law. Civil war is subject essentially to the jurisdiction of the enemy. Thus, civil war has a narrow, specifically dialectical relation to law. It cannot be anything other than just in the sense of being self-righteous, and on this

\footnotetext{
${ }^{50}$ Schmitt uses the term 'international civil war' for the first time in 1938 in his Leviathan. He starts using the term 'universal civil war' a year later in his 'Neutralität und Neutralisierungen', in Positionen unde Begriffe im Kampf mit Weimar-Genf-Versailles, 1923-1939 (Berlin: Duncker \& Humblot, 1994 [1940]), p. 325. See

51 See, for instance, Ernst Jünger, The Peace (Hinsdale Il: Henry Regnery Company, [1947] 1948); Reinhardt Koselleck, Critique and Crisis: Enlightenment and the Pathogenesis of Modern Society (Cambridge MA.: MIT Press, [1959] 1988); Ernst Nolte, 'Weltbürgerkrieg 1917-1989', in Totalitarismus im 20. Jahrhundert: Eine Bilanz der internationalen Forschung, ed. Eckhard Jesse (Baden-Baden: Nomos, 1996), pp. 357-369. On the history of the concept see Hanno Kesting, Geschichtsphilosophy und Weltbürgerkrieg: Deutungen der Geschichte von der Französichen Revolution bis zum Ost-West Konflict (Heidelberg: Winter 1959).

${ }^{52}$ Jouin, Le retour de la guerre juste, pp. 269-272; Ninon Grangé, 'Carl Schmitt, Ernst Jünger et le spectre de la guerre civile. L'individu, le "soldat", l'État', in N. Grangé (ed.), Carl Schmitt: Nomos, droit et conflit dans les relations internationales (Rennes: Presses Universitaires de Rennes, 2013), pp. $39-60$.
} 
basis becomes the prototype of just and self-righteous war. ${ }^{53}$

Roosevelt and Churchill's insistence on the 'unconditional surrender' of the Axis Powers at the Casablanca Conference of January 1943 confers a certain plausibly to Schmitt's theses. The most famous early use of the notion of 'unconditional surrender' goes back to the 1862 battle of Fort Donelson in the American Civil War, during which Brigadier General Ulysses S. Grant stated that 'no terms except an unconditional and immediate surrender' of the southern states can be accepted. $^{54}$ Like Jünger, Schmitt was perfectly aware of this precedent. What both men would come to realise during the early 1940s is that America's discriminatory war discourse was an ideological offshoot of the totalizing way of war developed during the American Civil War of 1861-1865. As one historian reminds us, the American Civil War contained practically all of the technological ingredients accounting for the total character of the First and Second World War: 'the mobilizations by railroad, the massive armies sent into battle, the automatization of killing resulting from the invention of the machine gun, the ambushes carried out by lurking submarines, the involvement and suffering of the civilian population, above all the fusion of warfare and economic productivity'. Nineteenth century Europeans were very much aware of these developments. But the significance and implications of this 'New World' phenomenon did not really begin to sink in until the FrancoPrussian War of 1870-71, which effectively ended the strategic culture forged by the Restoration of $1815 .^{55}$

Yet it is important to understand that Schmitt's global civil war discourse is not a claim that geopolitics since the First World War could plausibly be read as a continuous internationalised civil war, as in Ernst Nolte's revisionist history of the twentieth century. ${ }^{56}$ Rather, Schmitt mobilises the language of global civil war to highlight the fact that classical conceptual categories of warfare have lost their normative force and explanatory power in the historical period of transition that we have come to associate with 'globalisation'. What Schmitt perceived better than

\footnotetext{
${ }^{53}$ Schmitt, Nomos, pp. 56-57.

${ }^{54}$ See Michael Balfour, 'Another Look at Unconditional Surrender', International Affairs, vol. 46, no. 4, 1970, pp. 719-736.

${ }^{55}$ Dan Diner, Cataclysms: A History of the Twentieth Century from Europe's Edge (Madison: University of Wisconsin Press, 2008), p. 17.

${ }^{56}$ Ernst Nolte, Der Europäische Burgerkrieg 1917-1945, Nationalsozialismus und Bolschewismus (Berlin: Propylän Verlag: 1987); 'Weltbürgerkrieg 1917-1989'.
} 
anyone else at the time is that the techno-militarization weaved into the socioeconomic and political fabric of American foreign policy was transforming the role of imperial military force. Thanks to the superseding of naval power by air power, force would no longer be deployed to achieved clearly defined expansionist objectives, but for the indefinite objective of policing the globe in the name of abstract ideals and an abstract system of economic exchange that were in the process of stripping humankind of all its concrete ties to the earth:

My Nomos of the Earth is arriving at an appropriate historical juncture. The time is coming (Nietzsche said in 1881-1882) when the struggle for the domination of the earth will be fought; it will be fought in the name of fundamental philosophical doctrines; i.e. an ideological battle for unity. The Kellog Pact is opening a free path; war as a means of rational politics is despised, condemned; war as a means of global domination of the earth is the just war. As Martin Heidegger argues, the world becomes object. ${ }^{57}$

\section{Into the Abyss of Total Devaluation}

Schmitt's reference to Nietzsche and Heidegger in this diary entry from August 1950 announces another important twist that he is about to incorporate into his narrative in the coming decade. This concerns the rhetoric of 'values' that became so central to the ways in which the US and the USSR articulated their conflict over 'fundamental philosophical doctrines' during the Cold War. The key text here is a relatively unknown treatise that he wrote as a rejoinder to a conference paper given by his friend the conservative jurist Ernst Forsthoff on 'Virtue and Value in the Theory of the State' in 1959. Schmitt wrote another version in 1967, which was then re-printed with the original in 1979 as a small book entitled The Tyranny of Values. ${ }^{58}$ There, Schmitt draws on Heidegger's philosophical critique of values to construct a political critique of values linking back to his earlier discourse on technology and the just war doctrine.

As is widely acknowledged in the specialised literature, the modern language of values began to emerge in the mid-nineteenth century as an attempt to carve a space for freedom and moral responsibility in the face of rapid scientific modernisation. It did this mainly by opposing a realm of ideal valuations based on 'Weltenschauungen'

\footnotetext{
${ }^{57}$ Schmitt, Glossarium, 29/08/1950, p. 255.

${ }^{58}$ Carl Schmitt, The Tyranny of Values, trans. Simona Draghici (Washington D.C.: Plutarch Press, 1996).
} 
(comprehensive worldviews) to an objectivist scientific realm of being in which everything is causally understood. ${ }^{59}$ Like most observers during this period, Heidegger reads Nietzsche's re-valuation of all values as the definitive hinge between the nineteenth and twentieth century in this respect. Although he is in many ways sympathetic to Nietzsche's project, Heidegger argues that Nietzsche's uncritical appropriation of the language of values to confront the European crisis of nihilism had only succeeded in prolonging the agonising decline of the West. ${ }^{60}$

Without going into the fine details of Heidegger's analysis, the main issue is to do with the subjectivism by which values are called into being. Under the sway of modern physics and mathematics, subjectivism conceives of reality as a series of categories that the human subject has deliberately constructed and meaningfully projected onto the world. In doing so, subjectivism 'forgets' that beings always reveal themselves to us as meaningful before we make any value judgements about them: "In interpreting, we do not, so to speak, throw a "signification" over some naked thing which is present-at-hand, we do not stick a value on it; but when something within-the-world is encountered as such, the thing in question already has an involvement which is disclosed in our understanding of the world, and this involvement is one which gets laid out by the interpretation'. ${ }^{61}$

For Heidegger then, the problem is not to do with whether or not men should estimate certain normative goods over others (of course they should). Rather, the issue is that by elevating our insight into reality by considering it as 'value-ladden', we misconstrue everything that is not human (i.e. nature) in terms of a valueless and static realm of things. In doing so, we deracinate ourselves from Being as a dynamic event of self-emerging presence. As Heidegger explains in his 'Letter on Humanism' (1947), to assign value to something is to rob it of its worth, insofar as 'what is valued is admitted only as an object for man's estimation. But what a thing is in its Being is not exhausted by its being an object, particularly when objectivity takes the form of value. Every valuing, even where it is values positively, is a subjectivizing. It does not let beings: be. Rather, valuing lets beings: be valid - solely as the objects of its

\footnotetext{
${ }^{59}$ Charles Gray Shaw, 'The Theory of Value and its Place in the History of Ethics', International Journal of Ethics, vol. 11, no. 3, 1901, pp. 306-320; Herbert Schnädelbach, Philosophy in Germany, 1831-1933 (Cambridge: Cambridge University Press, 1984), pp. 161-191.

${ }^{60}$ Martin Heidegger, 'Nietzsche's Word: "God is Dead", in Off the Beaten Track, ed. and trans. Julian Young and Kenneth Haynes (Cambridge: Cambridge University Press, [1943], 2002), pp. 157-199.

${ }^{61}$ Martin Heidegger, Being and Time, trans. John Macquarrie and Edward Robinson (New York: Harper and Row, 1962 [1927]), pp. 190-191.
} 
doing, ${ }^{62}$ And so because the goal of this cognitive process is ultimately to control and use the material universe, subjectivism is not so much the antithesis of scientific objectivism as a more extreme form of nihilistic objectification. It is the very core of a modern scientific worldview in which ' $[\mathrm{v}] \mathrm{alue}$ and what is valuable are turned into a positivistic substitute for the metaphysical'. ${ }^{63}$

Heidegger rarely ever mentions Weber by name in his published writings. But it is obvious that Weber's famous distinction between scientific observation and subjective valuation based on worldviews is one of the main targets of his invectives against value thinking. Schmitt picks up on this in order to read his own provocative Hobbesian narrative into Weber's Vocation Lectures. According to Schmitt, Weberian political sociology constitutes the most insightful demonstration of the latent political violence nested in the elusive ontology of values. What Weber made clear for us is that since values are in fact only acts of valuation based on either tradition or charisma, their psychological and socio-cultural significance is nil unless they are accepted by others: "Value must continuously valuate, that is to say, it must bring its influence to bear: otherwise it dissolves into an empty manifestation'. ${ }^{64}$

For Schmitt then, the issue is not only that values presuppose an endless possibility of self-referential appraising positions: standpoint, viewpoint, vantage point, starting point etc. More fundamentally, it is that this pluralism is constantly abstracted and re-abstracted from the empirically determined position of individuals who, in reality, cannot valuate without simultaneously de-valuating in accordance with their own perceived interests: 'Whoever sets a value, takes position against a disvalue by that very action. The boundless tolerance and the neutrality of the standpoints and viewpoints turn themselves very quickly into their opposite, into enmity, as soon as the enforcement is carried out in earnest. The valuation pressure of the value is irresistible'. ${ }^{65}$ According to Schmitt, this is why Weber's famous distinction between an ethics of responsibility (in which the political actor is primarily concerned with costs, and takes personal responsibility for the 'foreseeable results' of his action) and an ethics of conviction (in which the political actor pursues certain ends or ideals, regardless of the cost) had proven to be completely untenable in the

\footnotetext{
${ }^{62}$ Martin Heidegger, 'Letter on Humanism', in Basic Writings, ed. David Farrell Krell (London: Routledge, 2002 [1947]), p. 251.

${ }^{63}$ Heidegger, 'Nietzsche's Word', p. 170.

${ }^{64}$ Schmitt, Tyranny.

${ }^{65}$ Ibid.
} 
technological context of the twentieth century:

the absolute value-freedom of scientific positivism is circumvented, and values are set free from it, in the opposite direction, namely, of the subjective world outlook. The genuinely subjective freedom of value-setting leads, however, to an endless struggle of all against all, to an endless bellum omnium contra omnes. In such circumstances, the very presuppositions about a ruthless human nature on which Thomas Hobbes' philosophy of the state rests, seem quite idyllic by comparison. The old gods rise from their graves and fight their old battles on and on, but disenchanted and, as we today must add, with new fighting means that are no longer weapons, but rather abominable instruments of annihilation and processes of extermination, horrible products of value-free science and of the technology and industrial production that follow suit. ${ }^{66}$

The reader perhaps sees where this is going. Because values are a form of secularised religious commitments but without the ontological clarity of theology, Schmitt argues that the techno-liberal resurrection of the just war tradition in the guise of values has rendered ideological conflicts 'more ghostlike and the fighters more dogmatic' than they ever were in the past. For if the abstract pluralism of values is inherently prone to degenerate into concrete relations of enmity, just war campaigns are inherently prone to degenerate into relations of total enmity: 'That lies in the nature of the thing itself. All respect for the opponent disappears - well, it turns into a disvalue - whenever the struggle against the opponent is a struggle for the highest value. Disvalue has no rights over value, and there is no price too high to pay in order to force the highest value through'. In this setting, all mediating criteria of both jus ad bellum and jus in bello fall 'hopelessly victim to this valuelessness. The urge to make values prevail becomes a coercion to enact values directly' ${ }^{67}$

Schmitt saw post-WWII America as the main symbol and vehicle of the technonihilism of values afflicting Western civilisation. Like Heidegger, he associated the scope, pace and intensity of the Cold War with the spaceless, ahistorical character of American narratives of identity. ${ }^{68}$ While insisting on the analogous uses and misuses that the two superpowers made of international legality in the name of humanity as a whole, Schmitt saw that the revolutionary character of American universals differed

\footnotetext{
${ }^{66}$ Ibid.

${ }^{67}$ Ibid.

${ }^{68}$ On Heidegger and America see James W. Ceaser, Reconstructing America: The Symbol of America in Modern Thought (Yale: Yale University Press, 1997), pp. 187-213.
} 
significantly from the universals of both the French and Bolshevik Revolutions. Whereas the continental revolutions were driven by a historical telos rooted in a preexisting political order that needed to be transformed, America invented a new order out of itself. The United States certainly possessed a chronicle of past events. But as an order of human and civil rights America had neither history nor ties to any spatial order. It was the ultimate utopia - literally, a 'no place'. Schmitt's point, of course, was that in reality the American utopia was just like any other legal-normative orders, underpinned by an original act of land appropriation, division and redistribution. Its projection onto the rest of the world after the Second World War was a reflection of this reality - a continuation of the logic of land and sea appropriation underpinning the Monroe Doctrine in the guise of industrial appropriation:

If you ask me what is the present nomos of the earth, I will answer without hesitation: it is the division and redistribution of the earth into industrially developed regions and underdeveloped regions, knowing that we must ask ourselves who offers development aid to whom and who accepts it from whom... It has its primary official source in article 4 of the Truman Doctrine expounded on 20 January 1949, which explicitly institutes this division while solemnly proclaiming that the industrial development of the earth is the plan and the goal of the United States. ${ }^{69}$

As for Soviet Russia, Schmitt believed that the alleged internationalism of the Eastern Bloc had never been anything else than a schizophrenic form of Soviet nationalism. On the one hand, this nationalism could only legitimise itself at home and abroad by virtue of its professed revolutionary enmity towards the liberal bourgeois values of the West. On the other hand, concrete differentials of power meant that Soviet foreign policy was factually driven by anxious efforts to find grounds for accommodation with the US. The aim was to share into the governance of this emerging liberal international order through the principle of 'spheres of influence'. This was not exactly the Entente Cordiale. But it was enough to prompt Stalin to intervene to prevent the success of communist revolutions in Greece and in Spain, and to sign a treaty of friendship with the anti-communist regime of Chiang

69 Carl Schmitt, 'L'ordre du monde après la Deuxième Guerre mondiale', in La Guerre Civile Mondiale, p. 81. My translation. This is a transcript from a conference that Schmitt gave in Spanish at the Instituto de Estudios Politicos in Madrid in 1962. As Céline Jouin points out in her editorial notes, Schmitt confuses the actual pronouncement of the Truman Doctrine before Congress on 12 March 1947, with the fourth point of Truman's 1949 inauguration speech. Note 9, p. 173. 
Kai-shek. The Tito-Stalin and Sino-Soviet splits, as well as the indecisive character and outcome of the Berlin Crisis and the Korean War were all manifestations of this pseudo-universalism. Although the genuine risk of a global revolutionary civil war had all but completely disappeared, the ideal could still serve as a pressure point in negotiations with the West. $^{70}$

Thus unlike many other realist analysts of the Cold War at the time, Schmitt did not associate the danger of nuclear annihilation with the security dilemma attending to the anarchical structure of the international state system. As we have seen, Schmitt believed that the legal-conceptual categories presupposed by such reified accounts of international anarchy had become a thing of the past. For him, what had become truly decisive since 1945 was the 'abyss of total devaluation' latent in the cultural fabric of globalising liberal modernity, which along with the disorientation of the theatres of war risked exceeding the rational limitations of the 'belligerent peace' cultivated by superpowers and supranational institutions. The danger here did not reside strictly in the disunity and devaluation intrinsic to the unification sought by the superpowers. It also stemmed from the fact that there would always exist terse powers and elements of resistance beyond the false East-West alternative. Schmitt saw that it was in the very nature of values and the horizontal mode of network governance through which they were instantiated and policed that they should bring back precisely what they purported to transcend: hierarchy, locality and identity. Resistance in this setting would take the form of the 'partisan' defined by his ties to soil, land and indigenous population and, most of all, by his irregularity and intensity: 'The modern partisan expects neither law nor mercy from the enemy. He has moved away from the conventional enmity of controlled and bracketed war, and into the realm of another, real enmity, which intensifies through terror and counter-terror until it ends in extermination'. ${ }^{71}$ As modern relationships of protection and obedience dissolved in the face of new technologies of aerial and nuclear warfare, police action against such 'criminals' and 'pests' would have to be intensified, and so would the justification of the methods:

Thus, the ultimate danger exists not even in the present weapons of mass destruction and in a premeditated evil of men, but rather in the inescapability of a moral compulsion. Men who

\footnotetext{
${ }^{70}$ Céline Jouin, 'Introduction' to Schmitt, La Guerre Civile Mondiale, p. 18.

${ }^{71}$ Carl Schmitt, Theory of the Partisan (New York: Telos [1963], 2004), p. 11.
} 
use these weapons against other men feel compelled morally to destroy these other men, i.e., as offerings and objects. They must declare their opponents to be totally criminal and inhuman, to be a total non-value. Otherwise, they are nothing more than criminals and brutes. The logic of value and non-value reaches its full destructive consequence, and creates ever newer, ever deeper discriminations, criminalizations, and devaluations, until all non-valuable life has been destroyed. ${ }^{72}$

\section{Conclusion: Schmitt and the Contemporary American Right}

We do not have to agree with Schmitt's nostalgic assessment of the Jus Publicum Europaeum to appreciate the foresight and conceptual fecundity of his analyses. When he wrote his treatises on values and partisan warfare in the late 1950s early 1960s, the Algerian War, the Vietnam War and the Portuguese Colonial War were in full swing, and the cultural revolutions were just about to kick off. In the United States this would lead to the collapse of the Cold War liberal consensus, and to the emergence of a whole new breed of 'value conservatism' that would forever change the face of mainstream American politics. ${ }^{73}$

As the Economist reported on the eve of the re-election of George W. Bush in 2004, it is in great part due to the steady rise of this so-called 'neoconservatism' that America has become so exceptional in the extent to which its politics tend to be determined by questions of religious and moral values rather than economics and traditional class politics. To be sure, the American political elites and political system tend to exaggerate the real extent to which these conflicts over values actually divide the polity. Political pundits, journalists and party activists - all share an interest in narratives of division rather than unity: 'The rise in partisanship has gone along with the decline of political competition, as gerrymandered safe seats proliferate and a tiny group of party activists gains growing leverage over the political system'. Yet the reason why this is the case is that those who feel strongly about cultural values are increasingly the only ones motivated enough to play a sustained proactive role in the political arena. ${ }^{74}$ And this, of course, was precisely Schmitt's point. For what is much less clear in all this is the ontological and epistemological status of the high

\footnotetext{
72 Ibid., p. 94.

${ }^{73}$ Peter Steinfels, The Neoconservatives: The Men Who Are Changing America's Politics (New York: Simon and Schuster, 1979); Sara Diamond, Roads to Dominion: Right-Wing Movements and Political Power in the United States (New York: Guilford Press, 1995); Drolet, American Neoconservatism.

${ }^{74}$ Economist, 'The Politics of Values', October $7^{\text {th }} 2004$, http://www.economist.com/node/3258082.
} 
moral ground from which neoconservatives condemn the liberal elites that they hold responsible for this unravelling of the American social compact. As Paul Gottfried pointed out, neoconservatives are "for "values" and against "relativism" while keeping their options open as to which values need defending'. ${ }^{75}$

And yet, if we put the rhetoric of 'values' aside for a moment, there are genuine affinities between our contemporary neoconservative politics and Schmitt's own Weimar critique of liberal democracy. For as in Schmitt, the ultimate aim of this cultural politics is to keep state and society as differentiated as possible so as to prevent issues of socio-economic exclusions and pluralism of interests to enter the realm of democratic politics. Over the past few decades, this has taken the form of various campaigns against multiculturalism, feminism, 'cultural Marxism', cosmopolitanism and other post-national ideologies perceived to be weakening state authority, empowering minorities and undermining the hegemony of the majority culture.

That these politico-cultural reactions exhibit strong tendencies to feed into belligerent foreign policy programmes should not surprise us. The sublimation of domestic challenges through military expeditions and foreign policy grand strategizing has been one of the most constant themes in the history of international relations. But what reading Schmitt in this context also highlights for us is the important linkage between these domestic culture wars and the American Right's hostility towards international law. Beyond traditional realist concerns over the inexpediency of multilateral diplomacy and the lack of viable enforcement mechanisms, the Right has a vested interest in opposing the constitutionalisation of the global liberal order simply because the pluralist, procedural ethics that underpins the latter reduces the scope for a moralisation of politics outside of positive law. In doing so, international law mines the authority of the ethnocentric universals that are so central to the hegemonic discourse of the majority culture and deprives the Right of its favourite terrain. As we have seen in the past three decades or so, the scope of these sovereigntist discourses go way beyond the alleged 'internationalisation of the domestic legal order' by human rights regime and environmental protocols. It also extends to a whole range of issues concerning the use of force, from the Mine Ban Treaty and ABM Treaty to the authority of the Security Council, the Geneva

\footnotetext{
${ }^{75}$ Paul Edward Gottfried, Conservatism in America: Making Sense of the American Right (New York: Palgrave Macmillan, 2007), p.53.
} 
Conventions and the Convention on Torture to fight terrorism. ${ }^{76}$

Apart from their one-sided nature, what is peculiar about these sovereigntist discourses is the fact that their protagonists understand them to be perfectly in line with America's historical role as the main purveyor of universal values to the rest of the world. As Robert Kagan so candidly explained in the aftermath of America's 2003 invasion of Iraq: 'By nature, tradition, and ideology, the United States has generally favored the promotion of American liberal principles over the niceties of Westphalian diplomacy. Despite its role in helping to create the UN and draft the UN Charter, the United States has never fully accepted the organisation's legitimacy or the charter's doctrine of sovereign equality'. ${ }^{77}$

It is this disregard for 'European style' procedural diplomacy that constitutes the main difference between Schmittian internationalism and neoconservative internationalism. Neoconservative discourses link American sovereignty with the self-realisation of an historical community of 'values' by affirming the ethnocentric universals of the majority culture over the formal processes of legality and interests mediation that endow international norms with a minimum of universal validity. As we have seen in the context of the war on terror, this tends to generate a particularly aggressive and totalising form of internationalism that is radically anti-pluralist both inside and outside the state and leaves no possibility for dissent to find any legitimate form of expression. This is a crusading form of conservatism that thrives on the cultivation of otherness and enmity while at the same time seeking to overcome all estrangement from the 'other' by putting enemies beyond the realm of humanity and cultivating contempt for dissenting friends and allies who challenge unmediated expressions of 'American values'.

Barack Obama's defence of the just war tradition to announce the escalation of the war in Afghanistan in his Nobel peace prize acceptance speech in December 2009 also highlights the continued relevance of Schmitt's analyses beyond the Bush presidencies. To be sure, Schmitt's geopolitical distinction between land and sea has long dissolved into an a-spatial globalization, in which drones controlled by computer geeks sitting in an Oklahoma basement are used for manhunts in the same

\footnotetext{
${ }^{76}$ For an overview see American Enterprise Institute Conference, 'Trends in Global Governance: Do They Threaten American Sovereignty?', Chicago Journal of International Law, vol. 347, Fall 2000. For a more substantive analysis see Jean-François Drolet, 'Containing the Kantian Revolutions: A Theoretical Analysis of the Neoconservative Critique of Global Liberal Governance', Review of International Studies, vol. 26, no. 3, 2010, pp. 533-560.

${ }^{77}$ Robert Kagan, ‘America’s Crisis of Legitimacy', Foreign Affairs, March/April, 2004, p. 19.
} 
mountainous caves that witnessed the Great Game a hundred years ago. Civilians in these new conflicts are no longer just suffering wars, but are also fighting them. One could also add that 'partisan' resistance to imperial universals in this globalised order can no longer be understood in terms of its ties to the land and locality. For the transnational network governance structure of most prominent terrorist and 'irregular' organisations these days simply mirror the political order that they seek to negate. Yet none of this seems to have diminished the relevance of the main provocation underlying Schmitt's US foreign policy narrative. And that is the possibility that the barbarian fury of organisations such as al-Qaeda and ISIS is not the extrinsic other of the liberal peace forged during the American century but a constitutive expression of its own nihilistic telos. 